\title{
The effects of the physical characteristics of the culture medium on the development of red seaweeds in tissue culture
}

\author{
R. R. Robaina, G. Garcia-Reina \& A. Luque \\ Dpto. Biologia, Universidad de Las Palmas de G.C., Box 550, Las Palmas, G.C., Canary Islands, Spain
}

Key words: callus, Gelidium versicolor, Grateloupia doryphora, Laurencia sp., osmolality, regeneration, solidity, tissue culture

\begin{abstract}
Explants of Gelidium versicolor, Grateloupia doryphora and Laurencia sp. were cultivated in Provasoli enriched seawater culture medium (PES) adjusted to several osmolalities $\left(0.5,0.7,1.0\right.$ and $\left.1.5 \mathrm{Os} \mathrm{kg}^{-1}\right)$ and solidities (agar concentration $=3,8$ and $15 \mathrm{~g} \mathrm{~L}^{-1}$ ). Osmolality was adjusted by dilution of seawater with distilled water (50,70 and 100\% seawater) and by $\mathrm{NaCl}$ addition. Explants of Laurencia sp. and Grateloupia doryphora showed bud regeneration and callus formation. Explants of Gelidium versicolor only showed bud regeneration. Osmolalities of 0.5 and $1.05 \mathrm{Os} \mathrm{kg}^{-1}$ inhibited or drastically reduced bud regeneration and callus formation. The highest callus formation and bud regeneration were observed at 0.7 to $1.0 \mathrm{Os} \mathrm{kg}^{-1}$. An increase in the agar concentration of the culture medium was positively correlated with callus formation and negatively correlated with bud regeneration. An increase in the percentage of seawater increased the solidity of the culture medium and was positively correlated with callus formation. Glycerol was an effective carbon source for the vegetative propagation of axenic explants of Grateloupia doryphora, promoting growth and bud regeneration. An increase in glycerol concentration in the culture medium increased its osmolality, inhibiting the growth of the explants and their morphogenetic development.
\end{abstract}

\section{Introduction}

The control of cell growth and development is still a problem in seaweed cell and tissue cultures (Saga et al., 1986; Polne-Fuller \& Gibor, 1987). Some authors have reported the formation of callus and callus-like structures induced by the semi-solid (agarized) state of the culture medium (Fries, 1980; Saga et al., 1982; Saga \& Sakai, 1983; Polne-Fuller \& Gibor, 1984; Garcia-Reina ct al., 1988). The solidity of the culture medium seems to be involved in callus induction, since other gelling compounds produced the same effects as agar (Polne-Fuller \& Gibor, 1987).

The role of carbohydrates in the growth and organogenesis of seaweed cell cultures remains equivocal (Lawlor et al., 1988). The addition of carbohydrates to the culture medium, without controlling osmolality, can obscure their role in seaweed growth.

The aim of the present work was to study the effects of solidity and osmolality of culture medium on callus induction and bud regeneration of several red seaweeds, as well as the effects of 
glycerol addition on the osmolality of the culture medium and as a carbon source.

\section{Materials and methods}

Gelidium versicolor (S. G. Gmelin) Lamouroux, Grateloupia doryphora (Montagne) Howe and Laurencici sp., an intertidal alga similar to Laurencia obtusa (Hudson) Lamouroux, were collected in Gran Canaria (Canary Islands). Voucher specimens are deposited in the herbarium of the Jardin Canario, Gran Canaria, Canary Islands, Spain (LPA), as sheets LPA 30 (Laurencia sp.), LPA 110 (Gelidium versicolor) and LPA 129 (Grateloupia doryphora).

Two hours after collection, explants were excised from apparently epiphyte-free, highly pigmented and sterile thalli. Laurencia sp. explants were apical secondary branches $1 \mathrm{~cm}$ long; Gelidium versicolor explants were cylinder-shaped fragments $(0.5 \mathrm{~cm}$ long) excised from the middle zone of the long primary branches. Grateloupia doryphora explants were disc fragments $(0.3 \mathrm{~cm}$ diam.) excised from the middle lower thallus. Explants were cleaned following the methods described by Garcia-Reina et al. (1988). After cleaning, Laurencia sp. explants were cut again to obtain cylinder-shaped explants $(0.5 \mathrm{~cm}$ long).

The culture medium was PES (Provasoli, 1968) adjusted to the different osmolalities and solidities in Table 1. Explants (195 per treatment) were cultivated in Petri dishes (15 explants in each) with $20 \mathrm{~mL}$ of the culture medium. Cultures were placed in a growth chamber at $20 \pm 2{ }^{\circ} \mathrm{C}$ with a day length of 18 hours and $27 \mu \mathrm{mol} \mathrm{m}^{-2} \mathrm{~s}^{-1}$ at the level of the Petri dishes provided by Sylvania Grolux daylight lamps.

Quantitation was made using the indices \% callus (percentage of cultivated explants forming disorganized structures) and \% bud (percentage of cultivated explants regenerating buds). For Laurencia sp., quantitation was made at 30 days of cultivation; for the other two species, at 15 days. The results were expressed as a percentage of those in the control treatment.

Axenic cultures of Grateloupia doryphora were
Table 1. Percent seawater and $\mathrm{NaCl}$ or glycerol addition to the culture media used in osmolality variation exeriments (agar concentration in all the media $=8 \mathrm{~g}^{-1}$ ).

\begin{tabular}{lllll}
\hline $\begin{array}{l}\text { Culturc } \\
\text { media } \\
\text { notation }\end{array}$ & $\begin{array}{l}\text { Percent } \\
\text { seawater }\end{array}$ & $\begin{array}{l}\mathrm{NaCl} \\
\text { addition } \\
\mathrm{mol} \mathrm{m}^{-3}\end{array}$ & $\begin{array}{l}\text { Glyccrol } \\
\text { addition } \\
\mathrm{mol} \mathrm{m}^{-3}\end{array}$ & $\begin{array}{l}\text { Osmolality } \\
\text { Os Kg-1 }\end{array}$ \\
\hline PES50 & 50 & - & - & 0.5 \\
& & 0.10 & - & 0.7 \\
& & 0.27 & - & 1.0 \\
PES70 & \multirow{2}{*}{70} & 0.51 & - & 1.5 \\
& & - & - & 0.7 \\
& & 0.17 & - & 1.0 \\
& & - & - & 1.5 \\
PES & 100 & - & 0.30 & 1.0 \\
& & - & - & 1.5 \\
& & 0.25 & - & 1.0 \\
& & - & 0.50 & 1.5 \\
\hline
\end{tabular}

established following the methods described by Polne-Fuller et al. (1984). Semicircular-shaped explants (approx. $1 \mathrm{~mm}$ long) were excised from the axenic disc. Explants (15 semicircular explants per treatment) were cultivated in different culture media enriched with glycerol (Table 1) under the same culture conditions described before. Quantitation was made using the index 'number of buds/number of cultivated explants'. The fresh weight increase was monitored for semicircular explants cultivated in liquid PES70 + $0.3 \mathrm{M}$ glycerol and in PES.

\section{Results}

After 15 days calli (filamentous callus-like structures) and buds were regenerated by Grateloupia doryphora explants. During this time, the regenerating explants of Gelidium versicolor only produced buds; callus formation was not recorded even in explants cultivated for 45 days. The explants of Laurencia sp. developed callus (a compact cell mass in the wounded area of the explants) and buds after 30 days.

Callus and bud morphology were the same regardless of the osmolality or solidity of the culture medium. 


\section{Effects of osmolality}

The highest $\%$ callus and $\%$ bud were obtained in culture media at 0.7 to $1.0 \mathrm{Os} \mathrm{kg}^{-1}$. Culture media at $0.5 \mathrm{Os} \mathrm{kg}^{-1}$ or $1.5 \mathrm{Os} \mathrm{kg}^{-1}$ inhibited or drastically reduced regenerator (Figs. $1 \& 2$ ).

\section{Effects of solidity}

The agar content of the culture media was positively correlated to callus formation ( $\%$ callus) and negatively correlated to bud regeneration ( $\%$ bud; Fig. 3).
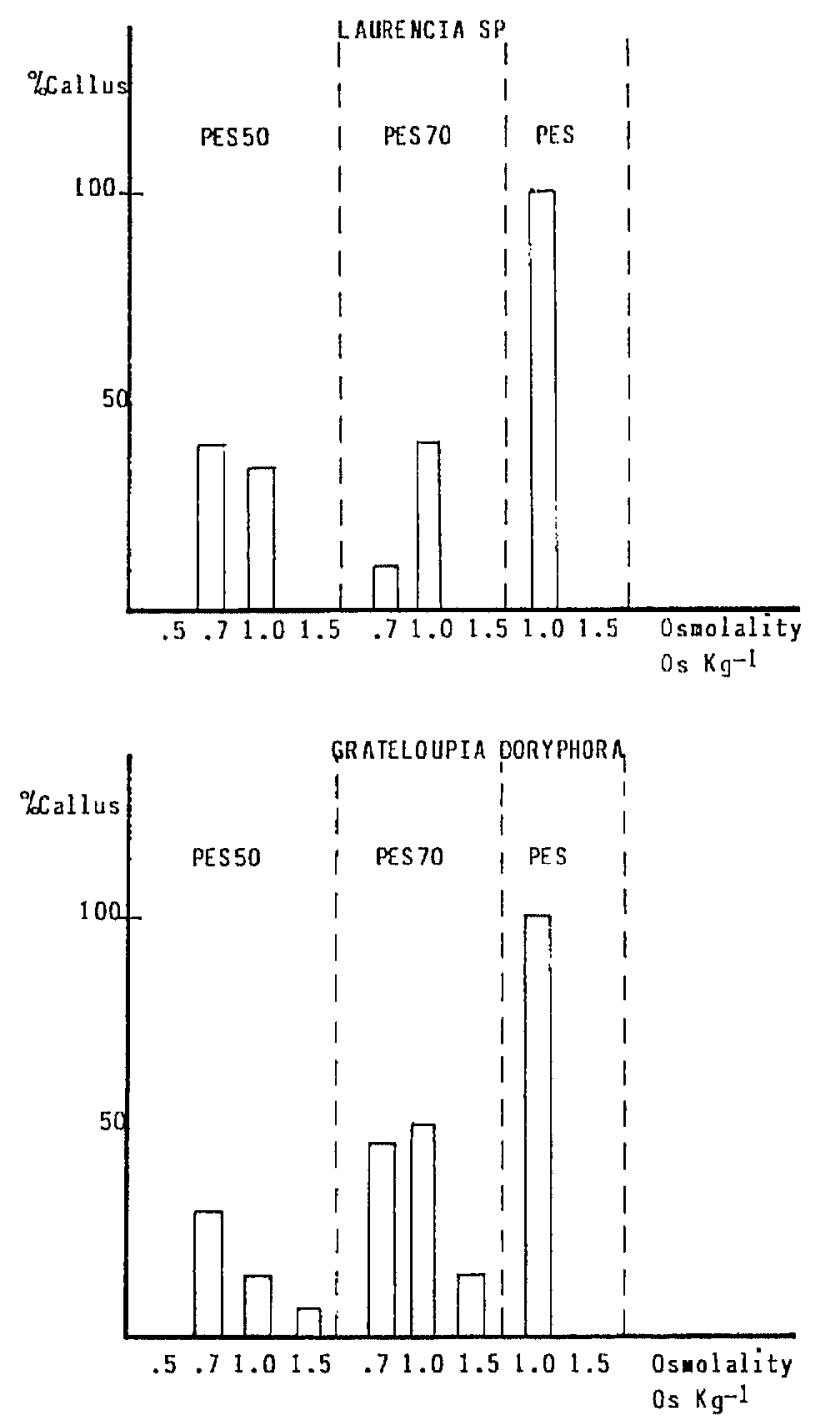

Fig. 1. Values of the index \% callus observed in explants cultivated in different osmolalities (agar concentration = $8 \mathrm{~g} \mathrm{~L}^{-1}$ in all media, $n=195$ ).
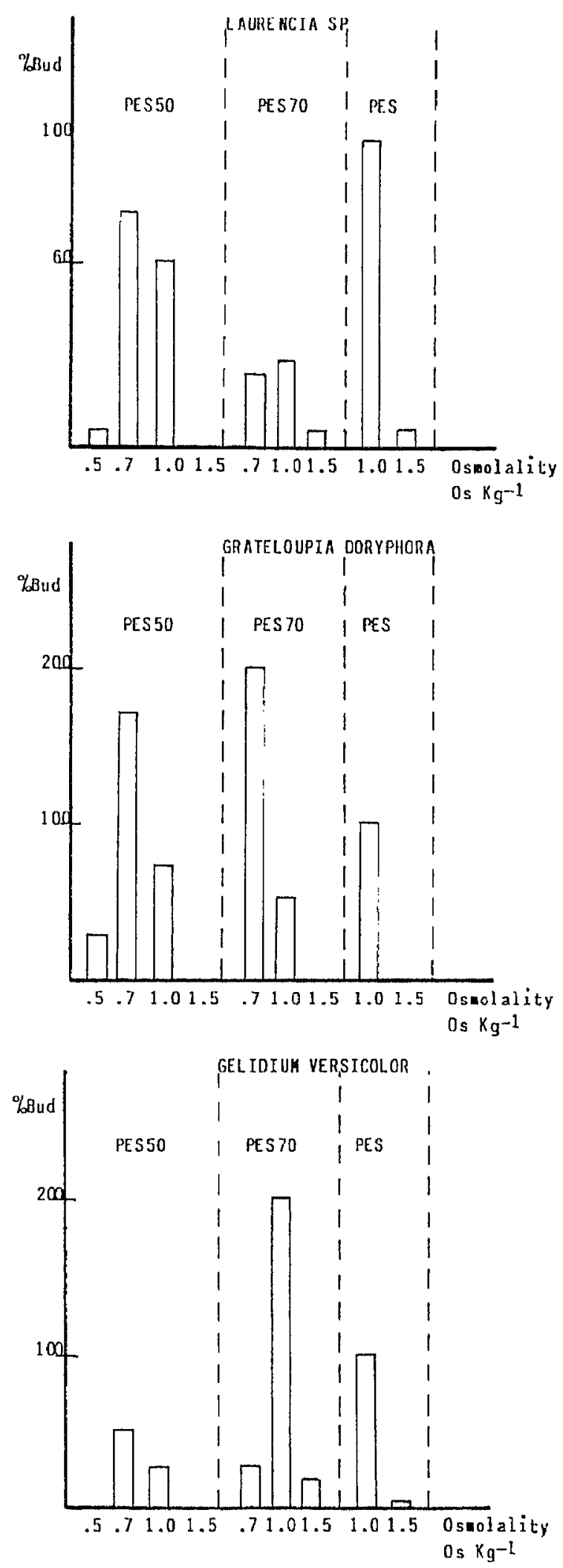

Fig. 2. Values of the index $\%$ bud observed in explants cultivated in different osmolalities (agar concentration = $8 \mathrm{~g} \mathrm{~L}^{-1}$ in all media, $\left.n=195\right)$. 

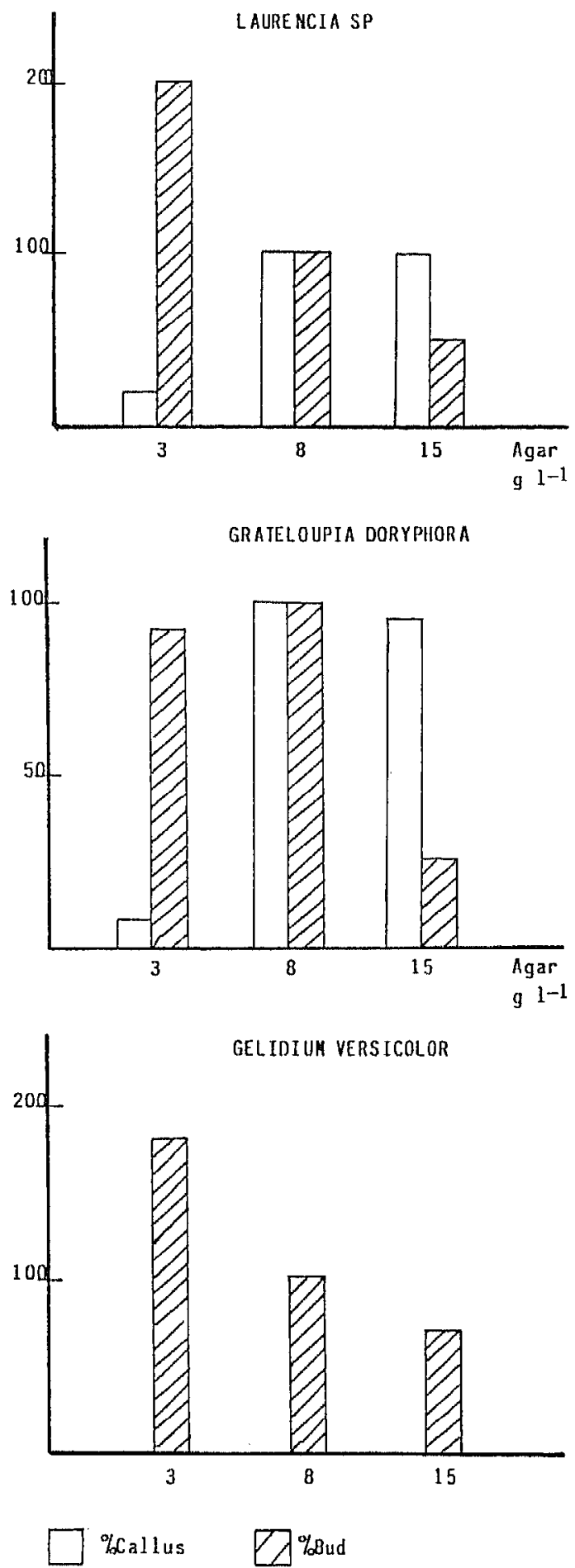

Fig. 3. Values of the indices $\%$ callus and $\%$ bud observed in explants cultivated in PES culture medium with 3,8 or $15 \mathrm{~g} \mathrm{~L}^{-1}$ agar (osmolality $=1.0 \mathrm{Os} \mathrm{kg}^{-1}$ in all media, $n=195$ ).

\section{Effects of seawater}

A decrease in the solidity of the culture medium was observed from PES $(100 \%$ seawater) to PES50 (50\% seawater).

Callus formation in Laurencia sp. and Grateloupia doryphora decreased from PES100 to PES50 (Fig. 1). No direct relation between dilution of seawater and $\%$ bud formation was found, but the highest \% bud formation in Gelidium versicolor and Gracidaria doryphora was observed in PES70. For Laurencia sp. (Fig. 2), the highest \% bud formation was in PES100, followed by PES50, then PES70.

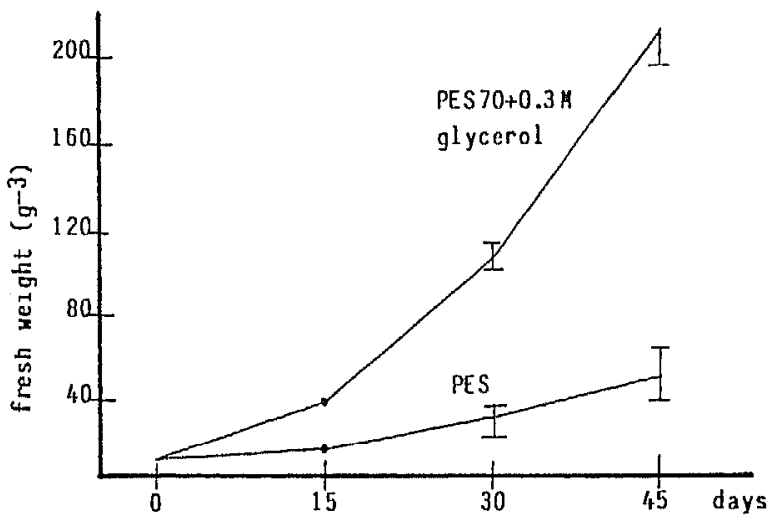

Fig. 4. Fresh weight increase of Grateloupia doryphora explants cultivated in liquid PES70 $+0.3 \mathrm{M}$ glycerol and in PES culture media.

Table 2. Values of the index 'number of buds/number of cultivated explants' (B/C) observed in explants cultivated in glycerol enriched media adjusted to different osmolalities and agar concentrations $(n=15)$.

\begin{tabular}{lclll}
\hline $\begin{array}{l}\text { Osmolality } \\
\mathrm{Os} \mathrm{kg}^{-1}\end{array}$ & $\begin{array}{l}\text { Agar } \\
\mathrm{g} \mathrm{L}^{-1}\end{array}$ & $\begin{array}{l}\text { Culture } \\
\text { medium }\end{array}$ & $\begin{array}{l}\text { Glycerol } \\
\mathrm{mol} \mathrm{m}\end{array}$ & $\begin{array}{l}\mathrm{B} / \mathrm{C} \\
\text { index }\end{array}$ \\
\hline 0.7 & 8 & PES70 & - & 7.10 \\
1.0 & 3 & PES70 & 0.3 & 18.25 \\
& 8 & PES70 & 0.3 & 16.25 \\
& 15 & PES70 & 0.3 & 6.25 \\
& 8 & PES & - & 7.20 \\
1.5 & 8 & PES70 & 0.8 & 2.60 \\
& 8 & PES & 0.5 & 1.51 \\
\hline
\end{tabular}




\section{Effects of glycerol}

Liquid PES70 $+0.3 \mathrm{M}$ glycerol gave a greater increase in fresh weight than liquid PES alone (Fig. 4). In solid media, the best results were obtained with a PES70 $+0.3 \mathrm{M}$ glycerol and 3 or $8 \mathrm{~g} \mathrm{~L}^{-1}$ agar; the explants became round, turned from reddish to orange, and reached a larger size than those in other culture media. Also, the highest values of the index 'number of buds/ number of cultivated explants' was observed in explants cultivated in that medium (Table 2). The value of this index decreased with increasing glycerol concentration and agar content of the culture medium (Table 2).

\section{Discussion}

The best morphogenetic response of an explant (callus and bud regeneration) was obtained at the 'natural osmolality' of $1 \mathrm{Os} \mathrm{kg}^{-1}$, the osmolality of the seawater, or slightly lower, $0.7 \mathrm{Os} \mathrm{kg}^{-1}$ (Figs. $1 \& 2$ ). Variation in the osmolality of the culture medium to 0.5 and $1.5 \mathrm{Os} \mathrm{kg}^{-1}$ inhibited or drastically reduced bud regeneration and callus formation.

When the explants were cultivated in media with optimum osmolality $\left(0.7\right.$ to $\left.1.0 \mathrm{Os} \mathrm{kg}^{-1}\right)$, the solidity of the culture medium affected the development of the explant, reducing bud regeneration and increasing callus formation (Fig. 3 ). The solidity of the culture medium is not only involved in callus induction (Polne-Fuller \& Gibor, 1987), but, in fact, in switching development from organized (bud) to disorganized (callus or callus-like) structures.

Lawlor et al. (1988) reported that an increase in salinity ( $\%$ seawater) of the solid medium promotes callus formation and growth in Ecklonia. The results in Fig. 1 show the same effect of seawater on callus formation in Laurencia sp. and Grateloupia doryphora. Also, the highest \% bud formation in $G$. doryphora and Gelidium versicolor was observed in PES50 or PES70 medium (Fig. 2). The fact that the solidity increased with the percentage of seawater in the PES medium clearly shows that the effect of seawater on callus and bud formation is due to the alteration of the solidity.

Glycerol is an effective carbon source for the vegetative propagation of Grateloupia doryphora. Liquid PES70 culture medium enriched with $0.3 \mathrm{M}$ glycerol gave an increase in fresh weight $400 \%$ higher than PES medium alone after 45 days. This result agrees with those reviewed by Fries (1973) on the effect of glycerol as a carbon source on red seaweeds.

The inhibiting effect of high concentrations of glycerol $(0.5$ and $0.8 \mathrm{M})$ on morphogenesis of the explants (Table 2) is primarily due to the increase in osmolality. This result demonstrates the need to control osmolality when testing the addition of carbohydrates or other osmotically active compounds on seaweed cell and tissue cultures.

\section{Conclusions}

Osmolality and solidity are physical characteristics of the culture medium that affect the vegetative propagation of Laurencia sp., Grateloupia doryphora and Gelidium versicolor by tissue culture. The alteration of the culture medium, such as dilution of seawater or addition of glycerol modifies the response of the explants by its own effect (i.e. carbon source effect of glycerol) and also by the modification of the solidity or osmolality of the culture medium.

\section{References}

Fries, L., 1973. Requirements for organic substances in seaweeds. Bot. Mar. 16: 19-31.

Fries, L., 1980. Axenic tissue cultures from the sporophytes of Laminaria digitata and Laminaria hyperborea (Phaeophyta). J. Phycol. 16: 475-477.

Garcia-Reina, G., R. Robaina \& A. Luque, 1988. Regeneration of thalliclones from Laurencia sp. (Rhodophyta). In M. S. S. Pais, F. Mavituna \& J. M. Novais (eds), Plant Cell Biotechnology. Springer-Verlag, Berlin: 81-86.

Lawlor, H. J., J. A. McComb \& M. A. Borowitzka, 1988. The development of filamentous and callus-like growth in axenic tissue culture of Ecklonia radiata. In T. Stadler, J. Moillon, M.-C. Verdus, Y. Karamanos, H. Morvan \& D. 
Christiaen (eds), Algal Biotechnology. Elsevier Applied Science, London: 139-150.

Polne-Fuller, M., M. Biniaminov \& A. Gibor, 1984. Vegetative propagation of Porphyra perforata. Proc. int. Seaweed Symp. 11: 308-313.

Polne-Fuller, M. \& A. Gibor, 1984. Developmental studies in Porphyra. I. Blade differentiation in Porphyra perforata as expressed by morphology, enzymatic digestion, and protoplast regeneration. J. Phycol. 20: 609-616.

Polne-Fuller, M. \& A. Gibor, 1987. Callus and callus-like growth in seaweeds: induction and culture. Proc. int. seaweed Symp. 12: 609-616.

Provasoli, L., 1968. Media and prospects for the cultivation of marine algae. In A. Watanabe \& A. Hattori (eds), Cultures and Collections of Algac. Jap. Society of Plant Physiol.: 63-75.

Saga, N., T. Motomura \& Y. Sakai, 1982. Induction of callus from the marine brown alga Dictyosiphon foeniculaceus. Pl. Cell Physiol. 23: 727-730.

Saga, N., M. Polne-Fuller \& A. Gibor, 1986. Protoplasts from seaweeds: Production and fusion. Beih. Nova Hedwigia 83: 37-43.

Saga, N. \& Y. Sakai, 1983. Axenic tissue culture and callus formation of the marine brown alga Laminaria angustata. Bull. jap. Soc. sci. Fish. 49: 1561-1563. 